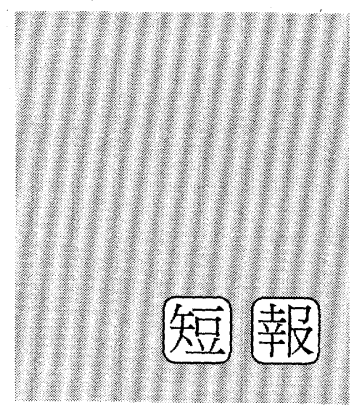

\title{
心身障害者の急性ストレスに対する 生理的反応*1
}

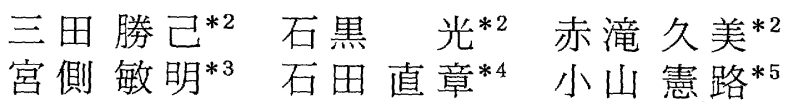

ーKey words : ストレス，心身障害者

要圆

心身障害者の急性ストレスに対する牛理的反心

$$
\text { 三丨勝己石黒光赤滝久美 }
$$

官側敏明石由值章少山悪路

重症し身障害児(者)，精神遅滞者を対象に精神的要因が高いと想定される蒾科喰 療 (㐘石除去) を䒠験的に行い, この急性ストレスに対する生理的反忘を分析した。 その反㕣指䅺には自律神経系として皮霄電気抵抗，体性神経系として筋電図とビデ オによる行動観察，両神経系の活動を反映する心拍数をとりあげた．健常者はこの ストレスを精神的負荷としてとられ、リラクセーションによって刘応しようとした。 精神道滞者もストレスを精神活動として認知するが，身体活動として解消する傾向 を示した。一方，重症心身障害兒（者）はこれを快不快といった感覚レベルでとら ネ，身体活動を通して反応した。

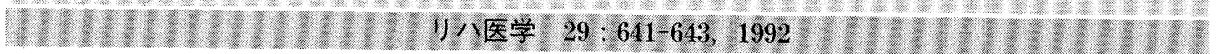

\section{はじめに}

重症心身障害児（者）をはじめ心身障害者の多くは 介護, 訓練, 治療行為や環境変化などの外的ストレス に適応したり，反応を表現する能力に乏しい豆，この ため，極端な場合には，介護中の骨折など事故の発生 を見落とすこともしばしば経験されるところである。 そこで, 外的ストレスとなる要因やその反応の特徵を 把握し，これを手掛りに表現力の乏しい彼らとの対話 を積極的に心掛け，至適な健康管理やリハビリテー ションを思考することがきわめて重要となる，本研究
では，その一つの試みとして，精神的要因が高いと想 定される歯科診療をとりあげ2,3), この受動的急性スト レスに対する生理的反応の特性を自律, 体性神経系の 両側面から分析した。

\section{方 法}

被検者好重症心身障害児（者）(以下，重症者之略) 6 名 (年歯 $17 \sim 30$ 歳), 精神遅滞者 5 名 (13〜23 歳) の計 11 名であった。重症者は大島の分類 1 が 5 名, 2 が 1 名であり，すべて IQは 20 以下であった，精神遅

1992 年 1 月 20 日受理

${ }^{*}$ Physiological Characteristics of Response to an Acute Stress with Dentistry in Mentally and Physically Disabled Persons

*2愛知県心身障害者コロニーノテ 480-03 春日井市神屋町 713-8

Katsumi Mrta, PhD, Hikaru Ishiguro, MD, Kumi AkATAKI, BS : Aichi Prefectural Colony

*3大阪市立大学 $/$ T 558 大阪市住吉区杉本 3-3-138

Toshiaki Mryagawa, PhD : Osaka City University

*4名古屋自由学院短期大学 $/$ 个 481 愛知県西春日井郡師勝町熊之庄

Naotaka IsHIDA, MS : Nagoya Jiyuu Gakuin Junior College

*5労災リハビリテーション工学センターノテ 455 名古屋市港区港明町 1-10

Kenji Koyama, BS : Rehabilitation Engineering Center for Employment Injuries 


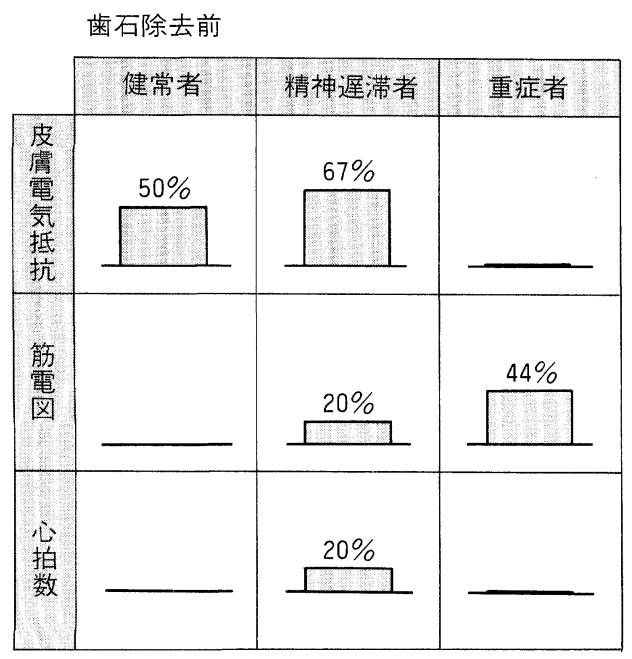

歯石除去中

図 歯石除去（スケーリング）前，中における皮膚電気抵抗，筋電図，心拍数の反応頻度

滞者の IQ は40〜55にわたった.

被検者は全員年 1 回の定期的な歯科治療の経験を もっていたが，本実験の直前に治療の必要な者はいな かった。な押，対照群として健常者 5 名（年齢 $18 〜 22$ 歳）を用いた。

測定は手掌の皮膚電気抵抗，腹直筋，大腿四頭筋の 筋電図，ビデオによる行動観察，心電図から算出した 心拍数の 4 項目について行った.

急性ストレスには一般に歯科診療の中で比較的強い 刺激と考えられる歯石除去（スケーリング）を選び, これを障害者歯科の専門医によって実施した，測定手 順としては，治療室と別な部屋において安静臥位状態 で被検者に電極等を装着し，この姿勢のままで治療室 へ移動させた。この後, 無影灯の点灯, 口腔洗浄に続 きスケーリング行為を数回行った.

\section{結 果}

図はスケーリング開始前およびスケーリング中の皮 膚電気抵抗，筋電図，心拍数の反応頻度を各被検者群 について示した. 刺激に対する反応は, 各測定パラメー タが安静時のレベルに比較して変化した場合,「反応あ り」と判定した。なお，これらのパラメータから反応 （ストレス）の強度を量的に評価することは困難である ので，主として頻度に注目した，すなわち，数回のス ケーリングに対して各個人毎の反応頻度を求め, これ をもとに各グループの平均頻度を算出した。
健常者の反応をみると, 筋電図, 心拍数ともにスケー リング前, 中で変化はみられず，ビデオによる行動観 察においても体の動きを認めなかった。一方，皮膚電 気抵抗はスケーリング前で $50 \%$, スケーリング中 $45 \%$ の頻度をもって変化を示した。

精神遅滞者はスケーリング前に筋電図, 心拍数の変 化が $20 \%$ 認められ，皮膚電気抵抗は $67 \%$ 確認された。 スケーリング中では筋電図が $60 \%$, 心拍数が $50 \%$ と高 頻度で出現した，皮膚電気抵抗についてはスケーリン グ前と同等であった，ビデオ観察ではスケーリング前 から逃避行動がみられ，それはスケーリング中でさら に顕著となった。

重症者についてみると，スケーリング前で皮膚電気 抵抗，心拍数の変化はほとんどみられなかったが，筋 電図は $44 \%$ に変化が認められた。 スケーリング中では 心拍数が $61 \%$, 筋電図は $96 \%$ に反応がみられ,さらに, 筋電図の振幅はスケーリング前よりも大幅に増大し た. ビデオ観察ではスケーリング前で筋緊張が充進し た状態や緩慢な動きがみられ，スケーリング中では刺 激行為から逃避するための身体活動がみられた。

\section{考 察}

本研究では，急性ストレスに対する対応を(1)身体内 部での調整活動（内部フィードバック）と(2)外部への 適応活動（外部フィードバック）の 2 面からとらえる こととし,神経系の情報を手掛りに検討を加えてきた。 
すなわち, 自律神経系の反応指標として皮膚電気抵抗, 体性神経系の指標に筋電図とビデオによる行動観察, 両神経系の活動を反映する心拍数をとりあげた．本急 性ストレス（スケーリング）前の皮膚電気抵抗の反応 は心理的ストレスを示すものであり，知的水準との密 接な関係が考えられる。

スケーリング前にお拈る健常者の皮膚電気抵抗の変 化は相当な頻度で観察された。ところが，その頻度は 実際のスケーリング行為に拈いてさらなる増加を示さ なかった，一方，筋電図および心拍数も刺激前，中に わたってまったく変化しなかった。急性ストレスは主 として交感神経系の六進を引き起こすが，単にそれの みではなく副交感神経系も同時に反応していると指摘 されている4)。このことは知的水準の高い健常者が副 交感神経を積極的に有意にさせ，ストレスを身体内部 で解消しようとしたことを推察させる。また，このよ うな推論はわれわれが緊張状態に直面した際に積極的 にリラックスを図ろうとした経験からも納得しうる。

一方, 本研究で対象とした精神遅滞者の場合, 心身 障害者の中では比較的知的水準が高いものの，このよ うな内的フィードバックは十分に発動されなかった。 すなわち，スケーリング中には顕著な筋電図の発現が みられ，逃避行動という外的フィードバックによる対 応を示した．さらに，心拍数の変化はこのような身体 活動と心理的ストレスの過大な元進の両者を反映した ものと考えられる。な拉,ここで対象としたのは中度
の精神遅滞者であり，本結果をもって精神遅滞者全体 の特性を代表させているとはいいがたい，軽度の場合 には健常者の反応に近づくことが想定され，重度では 下記の重症者の反応と類似性をもつことが推察され る.

重症者に関しては, 高頻度の筋電図，心拍数の出現 に比べ, 皮膚電気抵抗の変化がほとんど観察されな かった。このことはストレスを精神活動として認知す るのではなく，快不快といった感覚レベルでとらえ， 身体活動を通して反応したものと考えられる，以上の ように，心身障害者のストレスに対する反応機構は健 常者と異なり，知的水準によっても反応の様式に差異 がある、そこで，介護，治療，リハビリテーションな どにおいて彼らの反応特性を注意深く観察し，適切な 対応をすることが肝要であると考える.

\section{文 献}

1）児玉和夫：重症心身障害児・者の訓練で注意すべきこ と. 作業療法ジャーナル 25：643-646, 1991.

2) Devila JM, Menendez J : Relaxing effects of music in dentistry for mentally handicapped patients.

3) Corah NL, Pantera RE: Controlled study of psychologic stress in a dental procedure. J Dent Res 47: 154-157, 1968.

4）高橋幸夫：神経症，心身症における身体特性一安静時 および各種負荷時におけるポリグラフ的検討。心身医 $16: 336-348,1976$.

Editorial

\section{研究と報告}

日本医科大第二病院リハセンター 竹内 孝仁

廃用性萎縮筋におけるエネルギー代謝㧍よび糖代謝の観察

中枢神経障害児の摄食障害と摄食機能訓練に関する研究 …………高知県立子鹿園 時岡 孝光・他

リハビリテーション施設職員の性の知識と障害者の性への認識について

短 報

·鹿児島大附属霧島リハセンター 川平 和美・他

当院における脊䯣損傷者の坐骨部裖創発生・再発要因

第 29 回 日本リハビリテーション医学会 学術集会

会長講演

わが国における地域りハビリテーションシステムの展望・...

教育研修セミナー

肩関節障害に対するリハ処方 兵庫県立総合リハセンター 澤村 誠志 信原病院整形外科 信原 克哉 